\section{$\underset{\substack{\text { hommes } \\ \text { \& migrations }}}{ }$}

\section{Hommes \& migrations}

Revue française de référence sur les dynamiques

migratoires

$1280 \mid 2009$

Les Turcs en France : quels ancrages?

\title{
Diaspora turque et enjeux européens
}

\section{Marie Poinsot}

\section{OpenEdition \\ Journals}

\section{Édition électronique}

URL : http://journals.openedition.org/hommesmigrations/283

DOI : 10.4000/hommesmigrations.283

ISSN : 2262-3353

\section{Éditeur}

Musée national de l'histoire de l'immigration

\section{Édition imprimée}

Date de publication : 1 juillet 2009

Pagination : 1

ISSN : 1142-852X

\section{Référence électronique}

Marie Poinsot, "Diaspora turque et enjeux européens », Hommes \& migrations [En ligne], 1280 | 2009, mis en ligne le 29 mai 2013, consulté le 22 septembre 2020. URL : http://journals.openedition.org/ hommesmigrations/283; DOI : https://doi.org/10.4000/hommesmigrations.283 


\title{
Diaspora turque et enjeux européens
}

\author{
Par Marie Poinsot, rédactrice en chef
}

Voilà plus dix ans, la revue Hommes et Migrations consacrait un dossier à l'immigration turque en France en mettant l'accent sur les origines rurales et les stratégies migratoires, la pluralité de l'islam, la question kurde, les mobilisations familiales et la place des femmes, les médias turcs. À l'occasion de la Saison de la Turquie en France, Gaye Petek, la directrice de l'association ELELE, propose de compléter cette première approche. C'est pourquoi le dossier s'attache aux particularités de cette immigration à travers des points d'entrée thématiques tels que le mouvement associatif turc, l'identité des jeunes d'origine turque, les stratégies familiales et commerciales, l'implantation en milieu rural, l'islam transplanté et la vie de quartier etc.

Alors que cette immigration reste perçue dans l'opinion française comme discrète et silencieuse, elle fait l'objet de travaux universitaires encore limités, même si une nouvelle génération de chercheurs s'affirme en renouvelant les questionnements.

La dimension rurale de l'immigration turque en France, qui aurait pu s'illustrer également par des monographies sur l'Alsace où la visibilité des Turcs est forte, apparaît comme une des caractéristiques originales d'une population qui a su saisir les opportunités du tissu économique local et mettre à profit les possibilités de recrutement à travers les réseaux migratoires.

La lecture des articles montre que le cadre national n'est plus vraiment pertinent aujourd'hui pour appréhender la dynamique migratoire des Turcs en France et qu'il faut la replacer dans une perspective européenne, largement abordée dans ce dossier.

Un colloque rassemblait en mai dernier, à Ankara, 135 chercheurs venus de 15 pays pour confronter leurs travaux sur les cinquante années de l'immigration turque en Europe. II mettait d'ailleurs l'accent sur le poids démographique d'une diaspora forte de plus de 5 millions de personnes, installées dans les pays membres de l'Union, et sur les modalités de leur intégration dans les sociétés d'accueil qui s'articule avec des réseaux européens organisés autour d'appartenances religieuses ou politiques diverses.

Pour preuve, la moitié de cette population a acquis les nationalités des pays où ils résident et représente une force politique émergente dans certains pays. Elle pourrait compter dans le débat actuel sur l'entrée de la Turquie dans l'union européenne. Cette situation montre combien les enjeux sur l'avenir de l'Europe, de son élargissement et de ses identités, passent par la prise en compte des migrations passées et futures, notamment lorsque ces migrations relèvent d'une dynamique diasporique. 